\title{
PEMBERANTASAN TINDAK PIDANA KORUPSI Hukum Non Sistemik dan Hukum Profetik (Sebuah Tawaran Baru)
}

\author{
Oleh: \\ Gufroni, S.H., M.H.* \\ Email: gufroni_fhumt@yahoo.com
}

\begin{abstract}
This article examines the empirical facts about the failure of the state (government) to eradicate this already acute corruption. Although there are laws that regulate it and there is already a special commission to eradicate corruption, namely the KPK, many still fail. The main cause is that our law still adheres to the all-mechanical-formal-legalistic system built by legal positivism. So on that basis there needs to be a new formulation as an alternative effort to make Indonesia free from corrupt practices. This study uses two theoretical approaches, namely non-systemic law / chaos theory and prophetic law. According to chaos theory, Charles Sampford in his book entitled The Disorder of Law Critical of Legal Legal Theory is not seen as a system-mechanical building, but also as liquid reality. Chaos theory states, legal theory that must be understood as a systemmechanical chaos theory (according to the view of legal positivism) is clearly a mistake, that is a mistake from the beginning in photographing legal reality. The Prophetic law is one approach in understanding the contents of the verses of the Koran. This approach focuses more on empirical, historical and temporal aspects. In the prophetic paradigm, Kuntowijoyo understands that knowing God and learning revelation are important elements in explaining reality. He took this view from a Japanese scholar, Toshihiko Izutsu, who put up his work on the Semantic Al-Qur'an Field, in the title of God and Man in the Koran: Semantics of the Koranic Weltanchauung. Of the two new offers in the effort to eradicate corruption, it was found empirical facts that there is something wrong in understanding corruption itself so that it still remains a disease that threatens the moral of a nation. The key must be courage not to be confined in the shackles of the mechanically-formallegalistic positivism of law.
\end{abstract}

Key Word: Eradication of corruption, non-systemic law, prophetic law

\section{A. PENDAhULUAN ${ }^{1}$}

Korupsi di Indonesia tidaklah asing lagi di dengar oleh telinga. Bahkan setiap hari di media tak henti-hentinya mengabarkan tentang korupsi. Adapun korupsi yang merajalela di Indonesia seakan-akan tidak terbendung lagi. Baik itu ditingkat pusat sampai daerah terjangkit korupsi.

\footnotetext{
*Dosen Fakultas Hukum Universitas Muhammadiyah Tanggerang.

${ }^{1}$ Kompleksitas perkembangan perbankan ditandai dengan perubahan Undang-Undang Nomor 7 Tahun 1992 tentang Perbankan yang diubah menjadi Undang-Undang Nomor 10 Tahun 1998.
}

Korupsi adalah salah satu bentuk kriminal yang merusak disiplin nasional. Kerusakan disiplin nasional berakar dari hilangnya ketaatan individu terhadap peraturan ataupun hukum negara yang berlaku. Hal ini mengakibatkan tata kelola dalam pemerintahan dan masyarakat tidak akan berjalan berjalan dengan baik, kerugian finansial negara dan degradasi moral bangsa. Mengapa dikatakan demikian, sebab perilaku korupsi sudah menjalar di setiap lapisan masyarakat, mulai dari jabatan terendah 
seperti cleaning service hingga jabatan tertinggi seperti direktur. ${ }^{2}$

Sebahagian orang menyatakan bahwa korupsi di Indonesia sudah membudaya dan telah merasuki seluruh sendi-sendi kehidupan bangsa. Sebagian lain menyatakan bahwa korupsi belum membudaya, walaupun harus diakui korupsi telah sangat meluas. Bahkan dari laporan Bank Dunia itu, menemukan bahwa korupsi di Indonesia memiliki akar panjang ke belakang yaitu sejak jaman VOC sebelum tahun 1800, dan praktek itu berlanjut sampai masa-masa pasca kemerdekaan. Dari masa inilah Indonesia mewarisi praktek-praktek seperti membayar untuk mendapatkan kedudukan di pemerintahan, mengharapkan pegawaipegawai menutup biaya di luar gaji dari gaji mereka dan lain-lain. Pada masa Orde Baru yaitu selama 1967-1998, praktek korupsi ini mendapat dukungan dan kesempatan luas pada masa itu yaitu dengan memberikan dukungan kepada pengusaha-pengusaha besar dan membangun konglomeratkonglomerat baru dan memberikan kemudahan-kemudahan dan fasilitas, bahkan memberikan kesempatan kepada para pengusaha dan kroni Presiden untuk mempengaruhi politisi dan birokrat.

Apabila kini ditengarai gejala korupsi telah meluas ke mana-mana, sampai ke pelosok, bersamaan dengan meluasnya otonomi daerah dan menyebar ke berbagai lembaga

\footnotetext{
${ }^{2}$ Mutiara Aerlang dkk, Pakar Rupia (Apa Kerja Koruptor Indonesia?): Membangun Sanksi Psikososial Bagi Terpidana Kasus Korupsi, Jurnal Integritas KPK, Vol. 02, No. 1, Agustus 2016, Hal. 176
}

kekuasaan seperti legislatif, yudikatif, bahkan pers, penyebaran dan perluasan korupsi itu sebenarnya disebabkan oleh adanya penyebaran dan perluasan kekuasaan itu sendiri. Jika dalam era Orde Baru, korupsi berkembang di sekitar pusat kekuasaan pemerintahan; di era reformasi, korupsi berkembang kian luas mengikuti tren berkembangnya perluasan wilayah kekuasaan. ${ }^{3}$

Korupsi merajalela dan memasuki masa bulan madunya, yang telah tiba saatnya bagi orang-orang yang dahulu pada zaman Orde Baru belum menikmati manisnya korupsi, kini tiba giliran baginya. Oleh karena itu, jika pemerintah dan partai politik sekarang terkesan gamang dan lamban memberantas korupsi, itu karena kenyataan menunjukkan terlalu banyak orang yang sudah terjerat tindakan korupsi baru akibat perluasan kekuasaan era reformasi, bahkan pejabat pemerintah, penguasa, dan politisi yang ada kini sangat mungkin menjadi bagian penting proses pergiliran kesempatan untuk korupsi itu sendiri.

Sejak lepasnya pemerintahan Orde Baru, masalah pemberantasan korupsi belum juga tertangani dengan baik. Niat untuk memberantas korupsi cukup kuat. Berbagai peraturan dan reformasi perundang-undangan tentang korupsi dilahirkan, tapi tidak membawa hasil yang memadai. Bahkan banyak korupsi baru yang terungkap justeru terjadi setelah masa reformasi.

\footnotetext{
${ }^{3}$ Musa Asy'arie, Korupsi, Kebudayaan, dan Politik Kekuasaan, Jakarta:PSAP Muhammadiyah bekerja sama dengan Partnership, 2004 hal. 11.
} 
Pemberantasan korupsi selama ini masih belum berjalan dengan baik. Hal ini ditandai masih banyaknya perilaku korupsi ditemui di Indonesia. Meskipun peran pemerintah sudah berusaha semaksimal mungkin untuk mengurangi dan memberantas korupsi dengan cara memberi hukuman yang berat seperti: tidak memberikan keringanan hukuman, mencabut hak memilih dan dipilih, dimiskinkan dan lain sebagainya. Namun upaya tersebut masih kurang efektif hal ini terbukti dengan masih adanya oknum-oknum di pemerintahan yang terlibat perilaku korupsi.

Walaupun mengalami kenaikan peringkat secara signifikan dari peringkat 107 di tahun 2015 ke peringkat 88 di tahun 2016, Indonesia hanya sedikit improvisasi di penilaian Corruption Perception Indeks (CPI) dari 34 poin di tahun 2015 menuju 36 poin pada tahun 2016 (Tranparency International Indonesia 2017: 12). Skor CPI berada pada rentang 0-100. Poin 0 berarti negara dipersepsikan sangat korup, sedangkan poin 100 dipersepsikan sangat bersih. Walaupun begitu, target pemerintah Indonesia sendiri yang berusaha mencapai skor CPI 50 poin belumlah tercapai. ${ }^{4}$

Berbagai upaya telah dilakukan untuk memberantas memberantas korupsi. Diantaranya dengan mengeluarkan peraturan perundang-undangan terkait tindak pidana korupsi seperti UU No. 32

\footnotetext{
${ }^{4}$ Agie Nugroho Soegiono, Agenda Open Government: Memerangi Korupsi Melalui Inisiatif Open Data, Jurnal Integritas KPK, Vol. 03, No. 2, Desember 2017, Hal. 6
}

Tahun 1999 sebagaimana diubah UU No. 20 Tahun 2001 tentang Pemberantasan Tindak Pidana Korupsi, UU Pencucian Uang, dan sebagainya. UU yang ada ini tentu diharapkan dapat memberi pengaturan dalam hal pencegahan dan pemberantasan tindak pidana korupsi. Bahkan Negara membentuk sebuah lembaga khusus pemberantasan tindak pidana korupsi bernama Komisi Pemberantasan Korupsi (KPK). KPK merupakan lembaga dengan kewenangan luar biasa dalam pemberantasan tindak pidana korupsi.

Namun demikian, tetap saja upaya pemberantasan tindak pidana korupsi masih saja mengalami hambatan. Ada banyak upaya agar korupsi tetap tumbuh subur oleh sebagian elit tertentu, sehingga upaya pelemahan terhadap agenda pemberantasan korupsi masih terus terjadi, dari mulai upaya pelemahan terhadap kewenangan KPK, kriminalisasi para pimpinan KPK, hak angket dan yang terakhir upaya menjadikan korupsi sebagai kejahatan biasa yang sedang digodok dalam pembahasan RUUKUHP.

Melihat kondisi tersebut, maka sebenarnya situasi saat ini bisa dikatakan Indonesia masih dalam keadaan terbelenggu oleh karut marut penegakan hukum, terlebih bagaimana upaya memberantas penyakit korupsi yang sudah menjalar ke berbagai sendi kehidupan. Tentu ada yang salah dalam melihat persoalan ini, tidak hanya dilihat dari sisi penegakan hukum semata tapi juga sangat terkait dengan kondisi objektif yang harus dilihat secara general atau dalam perspektif 
yang luas. Bahwa sebenarnya hukum kita masih tetap saja terjebak pada arus positivisme yang masih berkutat pada undang-undang semata atau ilmu hukum itu sendiri.

Penegakan hukum dalam upaya pemberantasan tindak pidana korupsi masih berada dalam suatu kondisi yang masih chaos, belum stabil, mengalami pancaroba yang belum selesai kapan berakhir. Terbukti dari hari ke hari kian banyak orang yang terjerat kasus korupsi dan banyak diantara mereka yang sudah ditetapkan tersangka oleh KPK atau aparat penegak hukum lainnya. Penyebab utamanya adalah hukum kita masih menganut sistem yang serba mekanis-formallegalistik yang dibangun oleh positivisme hukum

Sehingga atas dasar itulah, perlu ada sebuah tawaran baru untuk dapat menyelesaikan situasi yang masih disorder tersebut di atas, terutama bagaimana korupsi yang sudah dianggap membudaya dapat dipangkas habis untuk masa yang akan datang. Perlu ada alternatif, ${ }^{5}$ agar persoalan di atas dapat di atasi, artinya perlu cara pandang baru yang mampu menjelaskan realitas hukum lebih utuh, sejalan dengan perubahan keilmuan yang terjadi akhir abad 20. Memasuki awal millenium, dunia dikejutkan oleh banyaknya temuan baru dalam bidang sains yang monumental, diantaranya teori kuantum modern, teori relavistik, juga teori chaos dan

\footnotetext{
${ }^{5}$ Anton F. Susanto, Ilmu Hukum Non Sistemik, Fondasi Filsafat Pengembangan Ilmu Hukum Indonesia, Genta Publishing: Yogyakarta, 2010, hlm. 7-8
}

fraktal. Teori-teori itu telah mengubah cara pandang manusia tentang alam semesta. Segala sesuatu yang awalnya dianggap sangat jelas dan pasti, berubah secara total. ${ }^{6}$ Perkembangan signifikan terjadi pula di wilayah ilmu hukum, sebagai reaksi terhadap pandangan sistem-mekanis-formal-legalistik yang dibangun oleh positivisme hukum, satu diantaranya adalah teori chaos dalam hukum. Menurut teori chaos, hukum tidak dilihat sebagai bangunan yang bersifat sistemmekanis, tetapi juga sebagai realitas yang bersifat cair. Teori chaos menyatakan, teori hukum yang harus dipahami sebagai teori chaos sistem-mekanis (menurut pandangan positivisme hukum) jelas merupakan kekeliruan, yaitu kekeliruan sejak awal dalam memotret realitas hukum.

Menurut Charles Sampford ${ }^{7}$ salah seorang eskponen terdepan pemikiran ini, kaum positivisme hukum telah memaksakan model pendekatan yang digunakan dalam ilmu kealaman terhadap ilmu-ilmu sosial, sehingga terjadi reduksi realitas yang luar biasa., realitas tidak dapat dilihat/dipahami sebagaimana adanya. Oleh karena itu, menurut Sampford, teori hukum tidak harus (tidak benar berupa teori hukum yang bersifat mekanis, tetapi dapat berupa teori ketidakteraturan (disorder/non-sistemis). Dalam teori chaos, realitas hukum harus

\footnotetext{
${ }^{6}$ Anton F. Susanto, ibid, hlm. 10

${ }^{7}$ Charles Sampford, salah satu pemikir yang mengembangkan model pendekatan chaos tersebut menjelaskan sebuah realitas yang bersifat melee, untuk meggambarkan relasi asimetris (tidak sistematis) yang terjadi dalam masyarakat. lihat Charles Sampford, The Disorder of Law: A Critique of Legal Theory.
} 
dipahami, dihayati, dan dimaknai secara mendalam karena hanya melalui cara tersebut, realitas hukum yang sesungguhnya dapat diungkap.

Selain melihat persoalan korupsi dari teori hukum non sistemik, juga tak kalah pentingnya ada tawaran baru yang lebih diterima akal dan hati manusia yakni teori hukum profetik guna menjawab realitas hukum di Indonesia. Dalam pandangan Islam $^{8}$, seluruh jagat raya terhubung Tuhan dalam suatu kesatuan kosmik. Pandangan ini menunjukkan adanya realitas absolut yakni Tuhan, dan realitas yang relatif pada struktur yang terluar atau terendah, yakni manusia dan alam. Ketegasan dalam menghubungkan manusia dan alam dengan aspek teologis ini begitu penting dan menghasilkan komunikasi ontologis, komunikasi etis, verbal melalui wahyu maupun non verbal melalui alam (hubungan pengetahuan) dan perbedaan status keduanya (Qs. XXXVII:67). Karena itu pada waktu yang sama, kita menyadari bahwa pandangan teologis ini menekankan adanya kesatuan, kesejajaran dan keseimbangan pada ranah realitas-realitas relaitf, yang sebenarnya dihimpun oleh kekuasaan ilahi. Pandangan tentang integralisme yang menghubungkan antara manusia, alam baik yang terlihat maupun tidak terlihat, alam eskatologis dan akhirat dalam hubungannya dengan Tuhan, pada gilirannya diadopsi oleh Kuntowijoyo dalam

\footnotetext{
${ }^{8}$ Absori, Kelik Wardiono, Saeful Rochman, Hukum Profetik, Kritik Terhadap Paradigma Hukum Non-Sistemik, Genta

Publishing:Yogyakarta, 2015, hlm. 323
}

membangun teorinya tentang ilmu-ilmu profetik.

Dalam paradigma profetik, Kuntowijoyo memahami bahwa mengenal Tuhan dan mempelajari wahyu merupakan unsur penting dalam mengeksplanasikan realitas. Pandangan ini diambilnya dari sarjana Jepang, Toshihiko Izutsu yang menubuhkan karyanya tentang Medan Semantik Alqur'an, dalam judul buku God and Man in the Koran: Semantics of the Koranic Weltanchauung, yang membahas secara seksama mengenai empat model relasi antara Tuhan dan manusia; relasi ontologis (pencipta-Makhluk), relasi komunikasi baik secara verbal melalui wahyu (wahy) maupun non-verbal melalui tanda (ayah), relasi status (tuan/rabb-hamba/abd), dan relasi etis (sifat Tuhan yang lembut (haliim) dan keras (syadid), selain itu juga menjelaskan konsep penciptaan hingga kematian (ajal) yang diatur melalui "masa" (dahr) sebagai orbitnya, nasib manusia berikut tipologinya (ahlul kitab, munafiq, muslim, dan kafir) dan masyarakat muslim, Konsep Allah dalam makna relasionalnya, Allah dalam perspektif paganisme arab, Yahudi dan Kristen, Konsep Yudeo-Kristen di tangan orang arab pagan, Allah sebagai Tuhan orang-orang hanif. Tidak berhenti disitu, Izutsu pun mengklasifikasikan alam dunia dan akhirat. Alam dunia ini menurutnya terdiri dari alam baik nyata (shahadah) maupun tidak kasat mata (ghayb) dan alam akhirat didirikan terdapat jembatan penghubung baik manusia yang memiliki hasil akhir dari perjalanan hidupnya baik sebagai muslim maupun kafir, 
diramunya dalam konsep-konsep eskatologis, yang terdiri dari hari akhir (as-sa'ah), hari kebangkitan (yaum ba'atsl ma'ad), hari perhitungan (yaum hisab) dan hari pengadilan (yaum qiyamah). ${ }^{9}$

\section{B. PEMBAHASAN}

\section{Pengertian Tindak Pidana Korupsi}

Dalam makna bahasa, korupsi adalah penyelewengan atau penyalahgunaan uang negara (perusahaan dan sebagainya) untuk keuntungan pribadi atau orang lain. Sedangkan dalam makna yuridis, istilah korupsi dapat dilihat dalam Pasal 2 dan Pasal 3 Undang-Undang No. 31/1999 Jo UU No. 20/2001 tentang Pemberantasan Tindak Pidana Korupsi, yang menyebutkan: Setiap orang yang secara melawan hukum melakukan perbuatan memperkaya diri sendiri atau suat korporasi yang dapat merugikan keuangan negara (Pasal 2). 2) Setiap orang yan dengan tujuan menguntungkan diri sendiri atau orang lain atau suatu korporasi menyalahgunakan kewenangan, kesempatan atau sarana yang ada padanya karena jabatan atau kedudukan yang dapat merugikan keuangan negara atau perekonomian negara (Pasal 3). 3) Merujuk pada ketentuan di atas, terdapat empat unsur penting dalam terminologi ini, yakni: (1) setiap orang; (2) melawan hukum (3) memperkaya diri sendiri/orang lain/ korporasi; dan (4) dapat merugikai keuangan negara atau perekonomian negara. ${ }^{10}$

Korupsi berasal dari bahasa latin, Corruptio-Corrumpere yang artinya busuk, rusak, menggoyahkan, memutarbalik atau menyogok. Korupsi merupakan fenomena sosial yang hingga kini masih belum dapat diberantas oleh manusia secara maksimal. Pengertian korupsi berdasarkan ketentuan Undang-Undang no 31 tahun 1999 tentang Tindak Pidana Korupsi (pasal 2 ayat 1), adalah "Setiap orang yang secara melawan hukum memperkaya diri sendiri atau orang lain, atau suatu korporasi, yang dapat merugikan keuangan negara atau perekonomian negara”. Dalam hal tentang pengertian yang merugikan keuangan negara atau perekonomian negara, maka secara implicit, maupun eskplisit, terkandung pengertian tentang keuangan atau kekayaan milik 'pemerintah', atau 'swasta', maupun 'masyarakat', baik secara keseluruhan maupun sebagian, sebagai unsur pokok atau elemen yang tidak terpisahkan dari pengertian negara (state).

Secara etimologis, kata korupsi (corruption) memiliki padanan kata Latin "corruptus" ataupun "corrumpere" yang berarti merusak, menghancurkan, membusuk, dan hancur berkeping (Skeat 1888, 136; Klein 1971, 169). Makna ini bersesuaian dengan penjelasan Aristoteles (2001) dalam

\footnotetext{
10 Undang-Undang Nomor 31 Tahun 1999 Yang Telah Diubah Dengan Undang-Undang Nomor 20 Tahun 2001 Tentang Pemberantasan Tindak Pidana Korupsi.
}

\footnotetext{
${ }^{9} \mathrm{lbid}, \mathrm{hlm} .234$
} 
karyanya De Generatione et Corruptione bahwa korupsi (corruption), sebagai lawan dari pembentukan/ pembangkitan (generation), mengacu pada sesuatu yang berhenti menjadi, yang mengalami kemerosotan, atau yang binasa. Pada seorang manusia, korupsi berarti kemerosotan pada kecenderungan berperilaku dari apa yang seharusnya menjadi perilaku manusia. Sedangkan pada konteks pemerintahan suatu Negara, korupsi berarti kemerosotan yang sifatnya sistemik terhadap praktik-praktik dan komitmen-komitmen yang membentuk sistem pemerintahan yang sehat (Buchanan 2004). Makna korupsi seperti itu lebih menekankan gambaran korupsi sebagai fenomena sistemik dari sudut pandang sesuatu yang terkorupsi. Masalahnya, gambaran korupsi sebagai fenomena sistemik cenderung melebih-lebihkan peran kebaikan bersama (common good) dan cenderung mengabaikan adanya kemungkinan bahwa tindakan tunggal (non-sistemik) yang koruptif bisa sama destruktifnya dengan korupsi sistemik.

Menurut Baharuddin Lopa, pengertian umum tentang tindak pidana korupsi adalah suatu tindak pidana yang berhubungan dengan perbuatan penyuapan dan manipulasi serta perbuatan-perbuatan lain yang merugikan atau dapat merugikan keuangan atau perekonomian negara, merugikan kesejahteraan dan kepentingan rakyat. Undang-undang pemberantasan tindak pidana korupsi (UU 31/1999), memberi pengertian tentang tindak pidana korupsi adalah "perbuatan memperkaya diri sendiri atau orang lain dengan melawan hukum yang dapat merugikan keuangan negara atau perekonomian negara" atau "perbuatan menyalahgunakan kewenangan, kesempatan atau sarana yang ada padanya karena jabatan atau kedudukan dengan tujuan menguntungkan diri sendiri atau orang lain serta dapat merugikan keuangan negara atau perekonomian negara". Termasuk dalam pengertian tindak korupsi adalah suap terhadap pejabat atau pegawai negeri. ${ }^{11}$

Kedua pengertian tersebut hanyalah dapat dimengerti dengan baik oleh para ahli hukum atau pejabat dalam bidang hukum. Kalangan awam menganggap bahwa pengertian korupsi bisa jauh lebih luas dari itu, yaitu segala perbuatan tercela yang dilakukan oleh pejabat dan pegawai negeri yang terkait dengan kekayaan negara. Apakah perbuatan itu merugikan negara atau tidak, hal itu bukanlah persoalan utama. Untuk mengkaji lebih jauh, kita merujuk pada apa yang dimaksud korupsi dalam undang-undang mengenai pemberantasan tindak pidan korupsi

\section{Unsur Tindak Pidana Korupsi}

Untuk mengkaji lebih jauh, kita merujuk pada apa yang dimaksud korupsi dalam undang-undang mengenai pemberantasan tindak pidana korupsi. Beberapa kata kunci yang merupakan unsur

11 Baharuddin Lopa \& Moh Yamin, UndangUndang Tindak Pidana Korupsi (Undang-Undang No. 3 tahun 1971) Berikut Pembahasan serta Penerapannya Dalam Praktek, Alumni, Bandung, 1987 
tindak pidana yang perlu didalami yaitu katakata:

- "perbuatan",

- "melawan hukum",

- "memperkaya diri sendiri atau orang lain",

- "merugikan keuangan/perekonomian negara",

- "menyalahgunakan wewenang, kesempatan atau sarana yang ada padanya,

- "menguntungkan diri sendiri atau orang lain". ${ }^{12}$

Persoalannya adalah apakah seluruh rangkaian "gambaran" atau "bayangan" dalam rumusan tersebut sudah mewakili pemahaman kita yang benar bahwa hal itu adalah korupsi? Atau ada yang salah dari penggambaran tersebut. Karena itu perlu dikaji lebih dahulu tentang hakekat atau makna dari penggambaran tersebut secara lebih mendalam.

Korupsi adalah rangkaian unsurunsur (rumusan) yang tertulis dalam undang yang dicocokkan dengan tindakan seseorang pada situasi konkrit. Rumusan dan unsurunsur tersebut masih merupakan "gambaran" atau "bayangan", yang masih berada dalam pikiran atau idea yang ditulis, dipositifkan dan dianggap sebagai sesuatu kebenaran. Rangkaian perbuatan konkrit dari "gambaran" atau "bayangan" tersebut adalah merupakan kejahatan, karena itu yang melakukannya dikenai hukuman. Apakah

12 KPK, Memahami untuk Membasmi: Buku Saku untuk Memahami Tindak Pidana Korupsi, 2006 hal. 6 betul rangkaian perbuatan tersebut adalah kejahatan? Dalam kerangka paham positivis "gambaran" atau "bayangan" tersebut dianggap benar dan dijadikan landasan dalam mengambil putusan bahwa perbuatan konkrit atas penggambaran tersebut adalah "kejahatan", tidak perduli apakah gambaran tersebut bertentangan atau tidak dengan etika atau moralitas dalam masyarakat. Etika dan moralitas menurut pandangan positivis berada di luar sisi hukum dalam penerapannya. Karena itu dari sisi pandangan positivis hal itu tidak perlu dibahas lebih jauh kecuali untuk keperluan ius constituendum (hukum yang dicita-citakan). Sebaliknya walaupun suatu perbuatan seorang pejabat atau pegawai negeri yang oleh masyarakat dianggap tercela tidak dapat dikatakan sebagai korupsi apabila tidak memenuhi unsur-unsur yang ditulis dalam undangundang atau sedemikian rupa tidak dapat ditafsirkan sehingga cocok dengan rumusan undang-undang. Inilah hal pertama yang harus dipahami tentang korupsi menurut positivisme hukum.

\section{Hukum Non Sistemik/ Teori Chaos}

Dalam hukum, teori chaos termasuk teori yang baru, dan berkembang sekitar tahun 70-80-an. Hampir tidak dapat ditemukan secara terperinci mengenai gagasan ini, karena masih sedikit ahli hukum yang mengkajinya. Namun Charles Sampford dalam bukunya berjudul The Disorder of Law A Critique of Legal Theory mencoba menyusun dan mengembangkan tentang teori hukum yang disebutnya sebagai teori chaos 
atau teori non-simetris/non mekanistik dalam hukum. Dari judul buku yang ditulisnya, Sampfrod mencoba menawarkan pandangan berbeda (baru) tentang apa yang selama ini dipahami teoritisi hukum. Semacam kegairahan baru dan radikal, karena selama ini chaos dalam hukum cenderung dipandang sebgai sesuatu yang sangat menakutkan. Menurut Satjipto Raharjo, buku itu menolak ide keteraturan dan kepastian yang melekat pada hukum positif, sebagaimana dipegang teguh kaum positivistik. ${ }^{13}$

Substansi buku itu adalah kritik argumentatif Sampfrod terhadap pemikir positivistik yang menyusun dan mengembangkan teori hukumnya berdasarkan model sistematis-mekanis. Sampfrod menjelaskan, masyarakat pada dasarnya tanpa sistem atau dalam kondisi asimetris yang disebutnya dengan social melee, dan hukum adalah bagian dari kondisi masyarakat tersebut, sehingga hukum ada dalam kondisi melee tersebut (legal melee). Bagi Sampfrod hukum penuh dengan ketidakpastian yang menurut Denis J. Brion dapat mengarahkan kita kepada pandangan nihilistik dalam hukum. Namun lebih dari itu, teori chaos dapat berfungsi sebagai metafor untuk melihat hukum dalam masyarakat dan menjelaskannya secara lebih baik dari pandangan-pandangan yang telah ada, sebagaimana diuraikan oleh Denis J. Brion. ${ }^{14}$

\footnotetext{
${ }^{13}$ Anton F.Susanto, IImu Hukum Non Sistemik, op cit, hlm. 98

${ }^{14}$ Anton F. Susanto, IImu Hukum Non Sistemik, op cit, hlm. 99
}

Bila melihat kondisi Indoenesia sat ini yang masih karut marut terlebih soal pemberantasan korupsi yang seolah masih seolah jalan ditempat pasca reformasi tahun 98 lalu, maka ini bukti negara masih chaos. Saat ini masih dikatakan berlaku sistem rezim transisi dari otoriter ke rezim reformasi. Nampaknya komitmen agar Indonesia bersih dari korupsi seolah-olah hanya angan belaka, meski KPK sebagai komisi khusus untuk memberantas korupsi berusaha mati-matian memerangi korupsi tersebut. Ada banyak tantangan dan hambatan yang harus dihadapi, sehingga harus ada upaya luar biasa untuk melawan praktik-praktik korupsi. Korupsi sangat terkait dengan moral dan etika.

Menurut Bertens, K. Bertens, mendudukkan kata 'moral' dengan menajamkan penggunaannya apakah dalam konteks nomina (kata benda) atau sebagai adjektiva (kata sifat). Kata 'moral' jika dipakai sebagai nomina, maka ia sama arti dengan 'etika Sedangkan kata 'moral' yang dipakai sebagai adjektiva, maknanya sama dengan 'etis'. Nilai-nilai dan norma-norma yang menjadi pegangan bagi seseorang atau suatu kelompok dalam mengatur tingkah lakunya. ${ }^{15}$

Kata yang lebih abstrak dari 'moral' adalah 'moralitas'. Menurut Bertens, 'moralitas' (dari kata sifat Latin 'moralis') mempunyai arti yang pada dasarnya sama dengan 'moral'. Hanya saja 'moralitas' ada nada lebih abstrak. "Moralitas adalah sifat

\footnotetext{
${ }^{15}$ K. Bertens, 2011, Etika, Cetakan Kesebelas, Gramedia, Jakarta, hlm.7.
} 
moral atau keseluruhan asas dan nilai yang berkenaan dengan baik dan buruk". ${ }^{16}$

Karena ini berhubungan dengan moralitas, maka tak heran banyak politisi, pejabat pemerintah pusat dan daerah, kalangan penegak hukum sendiri yang justru tidak memiliki moralitas yang baik. Mereka justru secara terang-terangan melakukan praktik korupsi secara berjamaah melibatkan berbagai pihak, termasuk para pemilik modal atau suatu korporasi. Kejahatan ini bisa dilakukan oleh siapapun. Dari data Komisi Pemberantasan Korupsi (KPK), 343 bupati/walikota dan 18 gubernur terlibat korupsi. Mereka umumnya tokoh politik. Sedangkan Indonesia memiliki 419 kabupaten, 93 kota, dan 34 provinsi. Tokoh publik, baik dari kalangan eksekutif, legislatif, dan yudikatif, sudah menggenapi pihak yang terlibat dalam korupsi. Lalu ada kalangan kampus, yakni rektor, mantan rektor, dan pejabat perguruan tinggi juga tersangkut kasus korupsi. ICW menyebut 296 kasus dalam 10 tahun terakhir dengan 479 tersangka dan Rp 619 miliar potensi kerugian negara. ${ }^{17}$

Jadi nampaknya tidak cukup hanya mengandalkan pada aturan hukum yang ada dan juga kehadiran KPK pun tak banyak memberi peran yang berarti justru realitas yang ada adalah upaya sistematis dari

\footnotetext{
${ }^{16}$ Ibid.

17 Sulaiman, Moralitas Antikorupsi Pengemban Hukum Teoritis di Indonesia, Proseding Seminar Nasional Transendensi Hukum, Prospek dan Impelentasi, Genta Publishing, Yogyakarta, 2017 hlm. 224-225
}

kelompok elit yang menginginkan agar agenda pemberantasan korupsi pelan-pelan mati dan tidak bisa lagi untuk menangkapi para koruptor. Upaya pelemahan terhadap KPK dan upaya menjadikan korupsi hanya sebagai kejahatan biasa yang dihukum dengan pidana ringan nampaknya akan selalu terjadi. Sudah berapa kali, misalnya upaya agar kewenangan KPK diamputasi atau dilemahkan, mulai upaya kriminalisasi terhadap para pimpinannnya hingga yang terakhir adalah hak angket terhadap KPK.

Namun demikian, harapan masyarakat agar Indonesia bersih dari korupsi pun tak kalah hebatnya. Perlawanan terhadap upaya pelemahan terhadap agenda pemberantasan korupsi makin gencar dilakukan utamanya kalangan masyarakat sipil dari mulai tokoh masyarakat, tokoh perguruan tinggi, tokoh agama, budayawan, kalangan CSO dan lainnya untuk merapakan barisan untuk bersama-sama melawan para koruptor.

Realitas ini menunjukkan adanya tarik menarik yang kuat antara kelompok yang tidak menginginkan agenda pemberantasan korupsi jalan sebagaimana mestinya, di pihak lain terutama masyarakat sipil yang begitu gigihnya melawan berbagai upaya pelemahan terhadap agenda pemberantasan korupsi. Sampai kapan ini berakhir, tidak ada yang bisa memastikan.

Realitas hukum sebagaimana dijelaskan diatas, justru menimbulkan ketidakteraturan hukum itu sendiri sebagaimana yang disampaikan Charles Sampford dengan teori chaos nya. Bahwa 
keteraturan hukum melalui penerapan hukum positif/ positivisme hukum justru melahirkan ketidakteraturan atau disorder. Maksud hati hukum untuk tertibnya hukum malah hukum itu yang melahirkan ketidaktertiban di masyarakat. nampaknya positivisme hukum yang diwujudkan dalam berbagai aturan hukum mengalami kesulitan untuk menjelaskan realitas yang ada.

Misalkan kita temukan dalam kasus Bibit-Chandra $^{18}$ yang sempat ramai dan mengundang banyak perhatian masyarakat. Dalam kasus itu kita melihat bagaimana penyelesaian hukum ternyata tidak harus diselesaikan sebagaimana proses yang sistematik teratur sesuai dengan prosedur yang ditetapkan undang-undang. Namun sebaliknya dapat diselesaikan di luar dari tatanan aturan, atau tatanan otoritas yang ada. Karakter formal yang lebih realitas kekuatan masyarakat, sehingga pada waktu itu presiden dan tentu saja melalui kekuatan media mengambil jeda atau markah dengan lahirnya tim delapan untuk merespon nilainilai keadilan di luar tatanan atau hukum formal dan memutuskan persoalan selesai tanpa harus melalui tatanan aturan yang formal tersebut. Pada posisi ini logika formal yang ditunjang oleh silogisme hukum tentu tidak dapat menjangkau hal demikian itu. Fokus presiden yang lebih mengutamakan kemaslahatan dan keadilan hanya dapat dijelaskan melalui logika kuantum, atau kita

\footnotetext{
${ }^{18}$ Anton F. Susanto, IImu Hukum Non Sistemik, op.cit, hlm 276
}

dapat menyebutnya sebagai logika rasa yang dipandu oleh kecerdasan EQ dan SQ. ${ }^{19}$

Charles Sampfrod menjelaskan tentang relasi kekuasaan yang rumit yang menimbulkan situasi di mana masyarakat tidak dapat dilihat sebagai sesuatu yang bersifat sistematik atau mekanistik. Di dalam masyarakat menurut Charles Sampfrod dengan mengutip pandangan Denis Wrong, penuh dengan relasi kekuasaan yang timpang dimana suatu kekuatan saling berbenturan dengan kekuatan lain sehingga menjadikan masyarakat itu tidak simetris (asimetris).

Dengan demikian, tidak dapat dikatakan relasi masyarakat senantiasa berada dalam kondisi yang teratur. Penggunaan-penggunaan kekuatan dalam masyarakat yang akibatnya menimbulkan benturan-benturan yang menghasilkan kondisi yang chaos tersebut. Hal ini akan lebih jelas melihat dalam konteks teks, bahwa kekuatan yang satu dengan kekuatan yang lain saling berbenturan dalam proses penafsiran. Misalnya relasi kekuasaan berlangsung, kelompok yang lebih kuat (politik, sosial, ekonomi) akan menggunakan cara-cara khusus yang sesuai dengan kemampuan mereka terhadap kelompok yang lebih lemah, demikian pula sebaliknya, sehingga tercipta ketegangan, tarik menarik, saling dorong yang menimbulkan benturan berbagai kepentingan, namun senantiasa masyarakat yang lebih lemah dapat menjadi korban. Relasi kekuasaan di atas memperlihatkan bahwa dalam masyarakat

\footnotetext{
${ }^{19}$ Anton F. Susanto, Ilmu Hukum Non Sistemik, op.cit, hlm 103
} 
senantiasa tercipta hubungan yang chaos atau sangat timpang. ${ }^{20}$

\section{Hukum Profetik}

Pemikiran transendental dapat dilihat pada pada nilai agama, spiritual, etika, dan moralitas yang penuh dinamika dan pergumulan yang lahir dalam rentang sejarah yang panjang. Ilmu modern yang selama ini berada dalam koridor hegemoni modernispositivistik dengan doktrin empiris, objektivis, dan rasional mulai digugat kaum pemikir transendental yang lebih mengedepankan nilai dan makna dibalik itu, sehingga tampak bangunan ilmu yang menjadi lebih terbuka dan utuh dalam merespon persoalan hidup dan kehidupan. Dalam hal ini, pemikiran transendental mulai mengangkat hal-hal yang sifatnya irasional dan metafisika (emosi, perasaan, instuisi, nilai, pengalaman personal, spekulasi), moral, dan spiritual sebagai bagian integral dalam memahami keilmuan. ${ }^{21}$

Danah Zohar dan Ian Marshall dalam Spiritual Intelllegence, The Ultimate Intellegencence", mengkritisi kegagalan peradaban barat dengan mengenalkan berpikir spiritual (spiritual tinking) dengan menggunakan pendekatan kecerdasan spiritual (spiritual quition) yang akan diperoleh kecerdasan yang paling sempurna

\footnotetext{
${ }^{20}$ Anton F. Susanto, Ilmu Hukum Non Sistemik, op.cit, hlm 104.

${ }^{21}$ Absori, Pemikiran Hukum Transendental dalam Konteks Pengembangan IImu Hukum Indonesia, Proseding Seminar Nasional Transendensi Hukum, Prospek dan Impelentasi, Genta Publishing, Yogyakarta, 2017 hlm. 15
}

(ultimate intelegen), dilakukan dengan cara menerabas garis-garis formalisme (existing intelegen) dan transendental, sehingga akan dapat diperoleh pemikiran baru yang mendekati kebenaran yang hakiki (the ultimate truth). Manusia perlu spiritual tinking karena dimasyarakat barat telah terjadi makna hidup di dunia modern (the crisis of meaning). Spiritual quition merupakan alat bagi manusia untuk dapat membangun berbagai perspektif baru dalam kehidupan, mampu menemukan cakrawala luas pada dunia yang sempit dan bisa merasakan kehadiran tuhan tanpa bertemu dengan Tuhan. SQ dapat digunaka untuk membangkitkan potensi-potensi kemanusiaan yang terpendam, membuat diri manusia semakin kreatif dan mampu mengatasi problem-problem esensial. SQ juga merupakan petunjuk ketika manusia berada di antara order dan chaos, memberi intuisi tentang makna dan nilai. ${ }^{22}$

Di sini tampak menunjukkan bahwa ilmu pada hakekatnya satu (the unity of knowledge) yang E. Wilson dikonsepkan dalam istilah "Consilience". Pergantian paradigma dalam ilmu fisika dari mekanik ke teori kuantum yang lebih komplek, memberi pelajaran sangat berharga kepada studi hukum atau ilmu hukum. Memahami hukum tidak cukup hanya menggunakan pendekatan mekanik-positivistik analitis, dilihat secara

\footnotetext{
${ }^{22}$ Absori, Epistimologi Ilmu Hukum Transendental dan Implementasinya Dalam Pengembangan Program Doktor Ilmu Hukum, Prosiding Seminar Nasional "Pengembangan Epistimologi IImu Hukum", Genta Publishing: Yogyakarta, 2015, hlm. 37
} 
linier dan mekanik dengan perlengkapan peraturan dan logika, kebenaran tentang kompleksitas hukum tidak akan muncul. Hukum telah direduksi menjadi institusi normative, psikologis, managerial dan lainlain tidak (boleh) ditampilkan. Batas antara order dan disorder dilihat secara hitam putih. ${ }^{23}$

Kuntowijoyo

memaknai transendental dengan mendasarkan keimanan kepada Allah (Ali Imron:110) dengan mengenalkan ilmu profetik, berupa humanisasi (ta'muruna bil ma'ruf), liberasi (tanhauna anil munkar) dan transendensi (tu'minuna billah). Dalam hal ini, unsur transendensi harus menjadi dasar unsur yang lain dalam pengembangan ilmu dan peradaban manusia. Metode pengembangan ilmu dan agama menurut Kuntowijoyo disebut dengan istilah profetik berdasarkan pada Al-Quran dan Sunah merupakan basis utama dari keseluruhan pengembangan ilmu pengetahuan. Al-Quran dan Sunnah dijadikan landasan bagi keseluruhan bangunan ilmu pengetahuan profetik, baik ilmu kealaman (ayat kauniyah) sebagai basis-basis hukum alam, humaniora (ayat Nafsiyah) sebagai basis makna, nilai dan kesadaran maupun ketuhanan (Ayat Qauliyah) sebagai basis hukum-hukum Tuhan. ${ }^{24}$

Profetik merupakan salah satu pendekatan dalam memahami kandungan ayat-ayat Al-Quran. Pendekatan ini lebih

\footnotetext{
${ }^{23}$ Absori, ibid, hlm 38

24 Absori, Kelik Wardiono, Saeful Rochman, Hukum Profetik, Kritik Terhadap Paradigma Hukum Non-Sistematik, Genta Publishing: Yogyakarta, 2015, hlm.ix
}

fokus pada aspek yang bersifat empiris, historis dan temporal. Model pendekatan ISP berupaya memahami kandungan ayat-ayat Al-Quran secara langsung tanpa melewati tafsir formal, berupa mengungkap maknamakna dalam kandungan Al-Quran lewat pendekatan ilmu. Menjadikan Al-Quran sebagai paradigma, untuk memahami realitas, Al-Quran mengkonstruksi realitas, karena itu perlunya dikembangkan tafsir sosial struktur melebihi tafsir individu, mengubah cara pandang dari subjektif ke objektif, mengubah pemahaman dari ahistoris ke historis, merumuskan formula-formula wahyu dari yang umum menjadi spesifik dan empiris. ${ }^{25}$

Garis pemisah yang tegas antara "basis/sumber dan etika" dan keilmuan barat yang bersumber pada akal (ratio/aql) dan keilmuan dari Islam yang bersumber dari Allah Swt berupa "wahyu" berupa struktur transendental dan akal (ratio/aql). Etika dari kedua sumber ilmu itu pun juga berbeda. Etika ilmu barat adalah humanisme, sedangkan etika keilmuan Islam adalah humanisme-theosentris. Ilmu Barat bersifat sekuler dan otonom, sedangkan ilmu Islam bersifat menyeluruh (integralistic). Hal tersebut merupakan cita-cita profetikyang diturunkan dari misi historis Islam sebagaimana terdapat pada QS. Ali Imran (110) yang berbunyi, "Engkau adalah umat terbaik yang diturunkan di tengah manusia

\footnotetext{
${ }^{25}$ Ridwan, Relasi Hukum dan Moral, Studi Dalam Perspektif Pemikiran Hukum Kodrat, Positivisme Hukum dan Hukum Profetik, Genta Publishing: Yogyakarta, 2017, hlm 79
} 
untuk menegakkan kebaikan, mencegah kemungkaran (kejahatan) dan beriman kepada Allah swt". ${ }^{26}$

Dalam khazanah hukum Islam, perilaku korupsi belum memperoleh porsi pembahasan yang memadai, ketika para fuqaha' berbicara tentang kejahatan memakan harta benda manusia secara tidak benar (akla mwal al-nas bi al-hbatil) seperti yang diharamkan dalam al-Qur'an, tetapi apabila merujuk kepada kata asal dari korupsi, maka dapat berarti merusak (dalam bentuk kecurangan) atau menyuap. Dalam konteks ajaran Islam yang lebih luas, korupsi merupakan tindakan yang bertentangan dengan prinsip keadilan (al-adalah), akuntabilitas (al-amanah), dan tanggung jawab. Korupsi dengan segala dampak negatifnya yang menimbulkan berbagai distorsi terhadap kehidupan negara dan masyarakat dapat dikategorikan termasuk perbuatan fasad, kerusakan dimuka bumi, yang juga amat dikutuk Allah SWT. ${ }^{27}$

Sebagai kejahatan yang berakibat luar biasa, maka korupsi dalam Islam pada dasarnya dapat dikategorikan sebagai perampokan terhadap harta Negara yang berimbas kepada kemiskinan karena perbutan seseorang yang bersifat sitematis dan mengakibatkan kepada kemiskinan

26 Khudzaifah Dimyati, Absori, Kelik Wardiono, Fitrah Hamdani, Hukum \& Moral, Basis Epistimologi Paradigma Rasional H.L.A Hart, Genta Publishing: Yogyakarta, 2017, hlm.24

27 Fazzan, Korupsi Di Indonesia Dalam Perspektif Hukum Pidana Islam, Jurnal IImiah Islam Futura Vol. 14, No. 2, Februari 2015 masyarakat. Secara umum, ada 3 (tiga) kategorisasi antara lain $:^{28}$

1. Korupsi merupakan perbuatan curang dan penipuan yang secara langsung merugikan keuangan negara dan masyarakat.

2. Korupsi diharamkan karena itu merupakan suatu perbuatan penyalahgunaan jabatan untuk memprkaya diri, keluarga dan golongan.

3. Korupsi merupakan perbuatan dzalim yang dilakukan oleh seseorang.

Korupsi merupakan suatu perbuatan curang karena merugikan keuangan negara serta merupakan penipuan terhadap kepercayaan masyarakat. "Tidak mungkin seorang Nabi berkhianat dalam urusan rampasan perang. Barang siapa yang berkhianat dalam urusan harta rampasan perang itu, maka pada hari kiamat ia akan datang membawa apa yang dikhianatkannya itu; kemudian tiap-tiap diri akan diberi pembalasan tentang apa yang ia kerjakan dengan (pembalasan) setimpal, sedang mereka tidak dianiaya.” (QS. Ali Imran:161). Dalam masa hidupnya Rasulullah menetapkan aturan yang berlaku bagi para pengikutnya waktu itu, dimana saat kembali dari tempat peperangan, seluruh harta benda rampasan perang harus dikumpulkan dan

28 Berdasarkan Fatwa MUI hasil Musyawarah Nasional VI Majelis Ulama Indonesia yang berlangsung pada tanggal 23-27 Rabi'ul Akhir 1421 H / 25-29 Juli 2000 M dan membahas tentang suap (Risywah) Korupsi (Ghulul) dan Hadiah kepada Pejabat, dimana menetapkan hukum sebagai berikut : 1 . Memberikan risywah dan menerimanya hukumnya adalah haram. 2 Melakukan korupsi hukumnya adalah haram. 
dilaporkan di hadapan pimpinan perang QS. Al-Anfal: 41).

Perlu diketahui bahwa seseorang yang telah melakukan korupsi, maka potensi jiwa sebagai pusat pembentukan moral atau karakter mulia akan rusak. "Seorang hamba itu bila berbuat dosa timbullah satu titik hitam (noda) dalam kalbunya. Bila dia bertobat dari perbuatannya maka kalbunya akan kembali bersih. Namun bila tidak bertobat dan menambah lagi perbuatan dosa, maka bertambahlah titik hitam tadi." (HR. Tarmidzi, an-Nasa'i dan Ibnu Majah). ${ }^{29}$

Coba perhatikan para koruptor di negeri ini. Banyak diantara mereka hidupnya menjadi berantakan. Keluarganya hancur, diceraikan istrinya dan anaknya terlibat narkoba. Rumah mewah tapi sepi bak rumah hantu, jauh dari kehangatan dan keceriaan. Seakan mereka sedang berduka, karena kepala keluarganya tersangkut kasus korupsi dan menjadi narapidana. Itu hukuman di dunia, belum di akherat kelak. Pastinya akan dijebloskan ke dalam siksa neraka. "Dan pada hari kiamat, kalian akan melihat orangorang berdusta terhadap Allah yakni mereka mukanya menjadi hitam. Bukankah dalam neraka jahannam itu terdapat orang-orang yang menyombongkan diri". (Qs AzZumar:60). ${ }^{30}$

\footnotetext{
${ }^{29}$ Gufroni, Berjamaah Lawan Maling, Jakarta: Pimpinan Pusat Pemuda Muhammadiyah, 2017, hlm. 66

${ }^{30}$ Gufroni, Berjamaah Lawan Maling, ibid hlm. 66
}

Korupsi merupakan perbuatan khianat terhadap amanat. "Hai orang-orang yang beriman, janganlah kamu mengkhianati Allah dan Rasul (Muhammad) dan (juga) janganlah kamu mengkhianati amanatamanat yang dipercayakan kepadamu, sedang kamu mengetahui" (QS. Al-Anfal: 27). "Sesungguhnya Allah menyuruh kamu menyampaikan amanat kepada yang berhak menerimanya, dan (menyuruh kamu) apabila menetapkan hukum di antara manusia supaya kamu menetapkan dengan adil ." (QS. AnNisa: 58). Kedua ayat ini mengandung pengertian bahwa mengkhianati amanat seperti perbuatan korupsi bagi pejabat adalah terlarang lagi haram.

Korupsi adalah perilaku aniaya. Perbuatan korupsi untuk memperkaya diri dari harta negara adalah perbuatan lalim, karena kekayaan Negara yang diperoleh adalah harta yang dipungut dari masyarakat termasuk masyakarat yang miskin. Oleh karena itu, amatlah lalim seorang pejabat yang memperkaya dirinya dari harta masyarakat tersebut. Allah SWT memasukkan mereka ke dalam golongan yang celaka besar. "Kecelakaan besarlah bagi orang-orang lalim yakni siksaan di hari yang pedih.” (QS. Az-Zukhruf: 65).

Suap dan gratifikasi menjadi salah satu bagian dalam golongan korupsi. Perbuatan ini oleh Rasulullah disebut laknat, "Allah melaknat orang yang menyuap dan menerima suap.”(H.R. Ahmad dan Hambali). "Barangsiapa yang telah aku pekerjakan dalam suatu pekerjaan, lalu kuberi gajinya, maka sesuatu yang diambilnya di luar 
gajinya itu adalah penipuan (haram).” (HR. Abu Dawud).

Orang yang melakukan kejahatan korupsi sesungguhnya mereka ingkar terhadap ajaran agama dan pelaku penistaan agama sesungguhnya. Korupsi itu bagian dari praktek mencuri harta negara. Sedangkan mencuri itu dalam Islam haram hukumnya. Korupsi memang telah merasuk ke dalam setiap sel darah bangsa kita. sebaik apapun moral kita, sulit menghindar dari praktik ini. Anggapan ini tidak salah. Mulai dari pengurusan kartu penduduk, pengadaan barang di instansi pemerintah, penggunaan fasilitas negara, hingga penaikan jabatan seorang pejabat publik rentan dengan penyelewengan uang negara yang notabene berasal dari keringat rakyat. Padahal negeri kita penduduknya merupakan muslim terbesar di dunia. Sungguh ini merupakan aib berkepanjangan bagi kita. ${ }^{31}$

Salah satu sebab korupsi adalah pandangan dunia (min-set) sebagian masyarakat yang keliru, yang dipengaruhi nilai-nilai agama dan budaya yang tidak kondusif bagi kehidupan yang bersih. Bagi banyak orang, agama atau iman lebih sering membelenggu dari pada membebaskan. Agama cenderung melangit, tidak membumi, mandul, tidak berdaya, kehilangan vitalitas, kurang menggerakkan penganutnya untuk aktif membebaskan diri dari perbuatan jelak, termasuk korupsi. ${ }^{32}$

\footnotetext{
${ }^{31}$ Gufroni, Berjamaah Lawan Maling, ibid hlm. 18

32 Muhamad Ali, Agama dan Korupsi, Kumpulan

Tulisan dalam Buku "Membasmi Kanker Korupsi"
}

Bagaimana mengobjektivikasi agama sehingga ia berperan positif terhadap upaya pemberantasan korupsi? Apabila pendekatan politik dan hukum lebih bersifat represif (meski juga bersifat preventif) dalam pemberantasan korupsi, maka agama berlaku lebih pada level preventif. Timbul anggapan, undang-undang antikorupsi dengan sendirinya akan menjamin penanggulangan korupsi. Padahal, hukum kurang menyentuh tataran preventif. Siapa yang dapat menjamin, gerak gerik seseorang setiap detik diperhatikan aparatur hukum? ${ }^{33}$

Agama, dalam konteks kekinian, memosisikan dirinya sebagai bimbingan dan kontrol transendental (ilahi). Bahwa penganut agama seharusnya merasa dikontrol oleh Zat yang Mahatahu kapanpun dan di mana pun dia berada. Selain itu, agama ada umumnya mengajarkan kehidupan sesudah mati. Bahwa meski tindakan korupsi yang dilakukan di sini sempat lepas dari pengawasan manusia, pengadilan di kemudian hari tidak akan melepaskannya. Keberagamaan yang substantif semacam inilah yang dapat mencegah penganut agama dari bertindak korupsi. ${ }^{34}$

\section{PENUTUP}

Korupsi adalah salah satu bentuk kriminal yang merusak disiplin nasional. Kerusakan disiplin nasional berakar dari

PSAP Muhammadiyah bekerja sama dengan Partnership: Jakarta, 2004, hlm. 231.

${ }^{33}$ Muhammad Ali, Agama dan Korupsi, Ibid, hlm. 231

${ }^{34}$ Muhammad Ali, Agama dan Korupsi, Ibid, hlm. 232 
hilangnya ketaatan individu terhadap peraturan ataupun hukum negara yang berlaku. Hal ini mengakibatkan tata kelola dalam pemerintahan dan masyarakat tidak akan berjalan berjalan dengan baik, kerugian finansial negara dan degradasi moral bangsa. Mengapa dikatakan demikian, sebab perilaku korupsi sudah menjalar di setiap lapisan masyarakat, mulai dari jabatan terendah seperti cleaning service hingga jabatan tertinggi seperti direktur.

Penegakan hukum dalam upaya pemberantasan tindak pidana korupsi masih berada dalam suatu kondisi yang masih chaos, belum stabil, mengalami pancaroba yang belum selesai kapan berakhir. Terbukti dari hari ke hari kian banyak orang yang terjerat kasus korupsi dan banyak diantara mereka yang sudah ditetapkan tersangka oleh KPK atau aparat penegak hukum lainnya. Penyebab utamanya adalah hukum kita masih menganut sistem yang serba mekanis-formallegalistik yang dibangun oleh positivisme hukum.

Perkembangan signifikan terjadi pula di wilayah ilmu hukum, sebagai reaksi terhadap pandangan sistem-mekanis-formal-legalistik yang dibangun oleh positivisme hukum, satu diantaranya adalah teori chaos dalam hukum. Menurut teori chaos, hukum tidak dilihat sebagai bangunan yang bersifat sistemmekanis, tetapi juga sebagai realitas yang bersifat cair. Teori chaos menyatakan, teori hukum yang harus dipahami sebagai teori chaos sistem-mekanis (menurut pandangan positivisme hukum) jelas merupakan kekeliruan, yaitu kekeliruan sejak awal dalam memotret realitas hukum.

Profetik merupakan salah satu pendekatan dalam memahami kandungan ayat-ayat Al-Quran. Pendekatan ini lebih fokus pada aspek yang bersifat empiris, historis dan temporal. Model pendekatan ISP berupaya memahami kandungan ayat-ayat Al-Quran secara langsung tanpa melewati tafsir formal, berupa mengungkap maknamakna dalam kandungan Al-Quran lewat pendekatan ilmu. Menjadikan Al-Quran sebagai paradigma, untuk memahami realitas, Al-Quran mengkonstruksi realitas, karena itu perlunya dikembangkan tafsir sosial struktur melebihi tafsir individu, mengubah cara pandang dari subjektif ke objektif, mengubah pemahaman dari ahistoris ke historis, merumuskan formula-formula wahyu dari yang umum menjadi spesifik dan empiris

Salah satu sebab korupsi adalah pandangan dunia (min-set) sebagian masyarakat yang keliru, yang dipengaruhi nilai-nilai agama dan budaya yang tidak kondusif bagi kehidupan yang bersih. Bagi banyak orang, agama atau iman lebih sering membelenggu dari pada membebaskan. Agama cenderung melangit, tidak membumi, mandul, tidak berdaya, kehilangan vitalitas, kurang menggerakkan penganutnya untuk aktif membebaskan diri dari perbuatan jelak, termasuk korupsi.

\section{DAFTAR PUSTAKA}

Al-Quran dan Sunnah 
Absori, Epistimologi Ilmu Hukum Transendental dan Implementasinya Dalam Pengembangan Program Doktor Ilmu Hukum, Prosiding Seminar Nasional "Pengembangan Epistimologi Ilmu Hukum", Genta Publishing: Yogyakarta, 2015

Absori, Kelik Wardiono, Saeful Rochman, Hukum Profetik, Kritik Terhadap Paradigma Hukum Non-Sistematik, Yogyakarta: Genta Publishing, 2015

Absori, Pemikiran Hukum Transendental dalam Konteks Pengembangan Ilmu Hukum Indonesia, Proseding Seminar Nasional Transendensi Hukum, Prospek dan Impelentasi, Genta Publishing, Yogyakarta, 2017

Agie Nugroho Soegiono, Agenda Open Government: Memerangi Korupsi Melalui Inisiatif Open Data, Jurnal Integritas KPK, Vol. 03, No. 2, Desember 2017

Anton F. Susanto, Ilmu Hukum Non Sistemik, Fondasi Filsafat Pengembangan Ilmu Hukum Indonesia, Genta Publishing: Yogyakarta, 2010

Baharuddin Lopa \& Moh Yamin, Undang-Undang Tindak Pidana Korupsi (Undang-Undang No. 3 tahun 1971) Breikut Pembahasan serta Penerapannya Dalam Praktek, Alumni, Bandung, 1987.

Fazzan, Korupsi Di Indonesia Dalam Perspektif Hukum Pidana Islam, Jurnal Ilmiah Islam Futura Vol. 14, No. 2, Februari 2015

Gufroni, Berjamaah Lawan Maling, Jakarta: Pimpinan Pusat Pemuda Muhammadiyah, 2017

Indriyanto Seno Adji, Korupsi dan Hukum Pidana, Kantor Pengacara dan Konsultan
Hukum Prof. Oemar Seno Adji \& Rekan, Jakarta, 2001.

Khudzaifah Dimyati, Absori, Kelik Wardiono, Fitrah Hamdani, Hukum \& Moral, Basis Epistimologi Paradigma Rasional H.L.A Hart, Genta Publishing: Yogyakarta, 2017

KPK, Memahami untuk Membasmi: Buku Saku untuk Memahami Tindak Pidana Korupsi, 2006

Muhamad Ali, Agama dan Korupsi, Kumpulan Tulisan dalam Buku "Membasmi Kanker Korupsi" PSAP Muhammadiyah bekerja sama dengan Partnership: Jakarta, 2004

Musa Asy'arie, Korupsi, Kebudayaan, dan Politik Kekuasaan, PSAP Muhammadiyah bekerja sama dengan Partnership: Jakarta, 2004

Mutiara Aerlang dkk, Pakar Rupia (Apa Kerja Koruptor Indonesia?): Membangun Sanksi Psikososial Bagi Terpidana Kasus Korupsi, Jurnal Integritas KPK, Vol. 02, No. 1, Agustus 2016,

Rahardjo, Satjipto., Ilmu Hukum, PT.Citra Aditya Bakti, Bandung, 2000

Ridwan, Relasi Hukum dan Moral, Studi Dalam Perspektif Pemikiran Hukum Kodrat, Positivisme Hukum dan Hukum Profetik, Genta Publishing: Yogyakarta, 2017

Sastrosoehardjo, Soehardjo Silabus Mata Kuliah Filsafat Hukum, Program Pascasarjana Ilmu Hukum, Universitas Diponegoro, Semarang, 1997

Sulaiman, Moralitas Antikorupsi Pengemban Hukum Teoritis di Indonesia, Proseding Seminar Nasional Transendensi Hukum, Prospek dan Impelentasi, Genta Publishing, Yogyakarta, 2017

T.M. Soerjanto Poespowardojo, Alexander Seran, Filsafat Ilmu 
Pengetahuan: Hakikat Ilmu Pengetahuan, Kritik terhadap Visi Positivisme Logis, serta Implikasinya (Jakarta: Kompas, 2015)

Undang-Undang Nomor 31 Tahun 1999

Yang Telah Diubah Dengan

Undang-Undang Nomor 20

Tahun $2001 \quad$ Tentang

Pemberantasan Tindak Pidana

Korupsi. 